\title{
Palliative Care for Cancer Patients: A Review
}

\section{Shubhangi khandekar ${ }^{1 *}$ Rohit B Moharil ${ }^{2}$, Alka Dive ${ }^{3}$ and Ashish Bodhade ${ }^{4}$}

${ }^{1}$ Professor, Department of Oral Pathology, VSPMDCRC, Digdoh Hills, Nagpur, India

${ }^{2}$ Senior lecturer, Department of Oral Pathology, VSPMDCRC, Digdoh Hills, Nagpur, India

${ }^{3}$ Professor and Head, Department of Oral Pathology, VSPMDCRC, Digdoh Hills, Nagpur, India

${ }^{4}$ Reader, Department of Oral Pathology, VSPMDCRC, Digdoh Hills, Nagpur, India

*Corresponding Author: Shubhangi khandekar, Professor, Department of Oral Pathology, VSPMDCRC, Digdoh Hills, Nagpur, India.

Received: August 20, 2019; Published: September 13, 2019

DOI: 10.31080/ASDS.2019.03.0640

\section{Introduction}

There is an ever - growing number of cancer patients in the world today. Of the estimated nine million new cancer cases diagnosed in 1997 worldwide, 52\% occurred in developing countries [1]. Cancer rates could increase by $50 \%$ to 15 million new cases in the year 2020 [2]. The mortality from cancer too is expected to rise around the globe. About 7 million deaths per year occur in the world due to cancer, of which, approximately 0.8 million occur in India [1]. In India one in 10 deaths is related to cancer and a sizeable section of this huge population die in unrelieved pain and suffering [3]. More than 70\% of all cancer patients in India require palliative care for relief of pain, other symptoms and psychosocial distress $[1,3]$. There is no cure to date for this disease but definitely a lot can be done to make the lives of these people meaningful and productive. With this idea the concept of palliative care was initiated.

What is palliative care?

Palliative care is interdisciplinary care that provides support for the physical, emotional, psychological suffering of patients and their families with any advanced illness, regardless of age, diagnosis or life expectancy [4].

\section{Model of palliative cancer care}

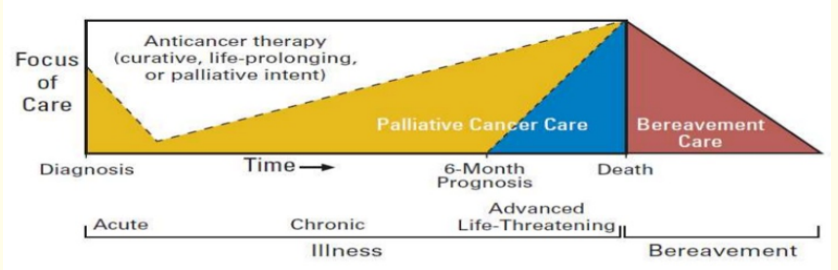

Figure 1: Model of palliative care.

(www. Google. balkan-mco-2011-r-curca-palliative-and-supportive-care-in-lung-cancer-3-728).
Components and principles of palliative care [4]

Key components of palliative care of cancer patients include compassionate communication

- Affirm life and regards dying as a normal process

- Neither hastens nor postpones death.

- Provides relief from pain and other distressing symptoms.

- Aims " To put life intio their days and not just days into their life"- I.e. to improve quality bof life.

- Aims at total care - physical, social, psychological and spiritual

- Is a team approach.

- Is individual specific - depends on assessment of patient and family needs.

- Shifts emphasis from technology to people -"high touch low tech"

- Is a partnership between the patient and the team.

- Emphasizes an open and sensitive communication.
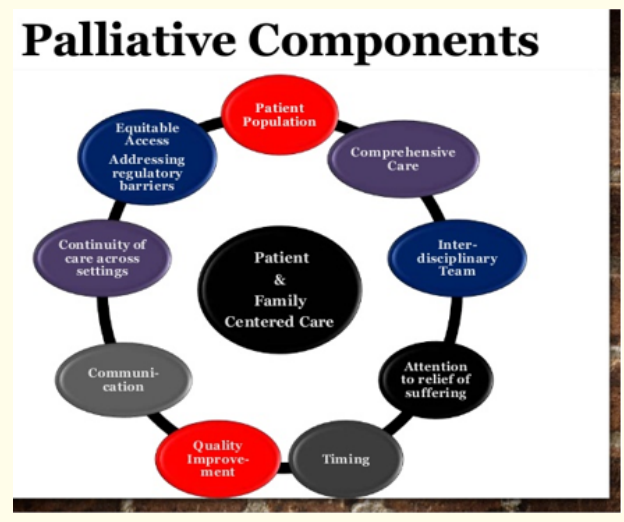

Figure 2: Components of palliative care.

(www.google.geriatric -population-geriatric-palliative-andendoflife-care-9-638). 
Principles of palliative care [4]

The four cardinal principles are

1) Non - Maleficence (Do no harm)

2) Beneficence (Do good)

3) Patient autonomy (Patient's right to be informed and involved in decision making)

4) Justice (balancing needs of individuals with that of society)

The four cardinal principles need to be applied against a background of

- Respect for life

- Accaptance of the ultimate inevitability of death.

- The potential benefits of treatment as against the potential risks and burdens

- Striving to preserve life but, when the burdens of life-sustaining treatments outweigh the potential benefits, withdrawing or withholding such treatments and providing comfort in dying.

- Individual needs balanced against those of society (manual)

\section{Concept of Home care [2,5]}

Caring for a patient with terminal illness at home is the preferred option for most people with a terminal illness

- The benefits of palliative care at home include a sense of normality, choice and comfort; and it is more cost - effective than hospital care.

- The responsibilities of a family caregivers may encompass some or all of the following: Personal care (hygiene, feeding); domestic care (cleaning, meal preparation); auxiliary care(shopping, transportation );social care (informal counselling, emotional support, conversing); nursing care (administering medication, changing catheters);and planning care( establishing and coordinating support for the patient ).Good palliative care can be delivered to patients at home by general physicians (supported by specialist palliative care teams ) and community nurses.

- Home care involves a considerable commitment on the part of family caregivers;

Need for palliative Care [3]

Patients diagnosed with a disease like cancer require not only physical control of disease and symptoms but also need help incoming to terms with their disease.

- Assistance in planning for life.
- It is necessary to show that you care about the patient as a person and not just concerned about physical symptoms.

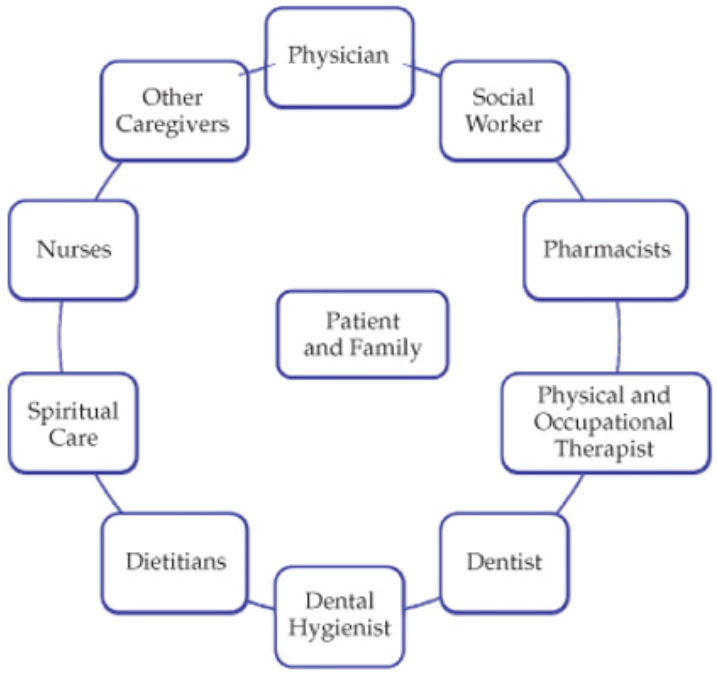

Figure 3: Concept of Home care.

Problems contributing to suffering in incurable illness [3]

- Pain

- Nausea/vomiting

- Fungating wounds /disfigurement

- Anorexia

- Breathlessness

- Loss of social needs

- Social isolation

- Dependency

- Change in faith/beliefs

- Personality changes

- Sadness

- Depression

- Denial

- Anger

- Fatique

- Anxiety

- Neglect

\section{Financial difficulties}

- Suffering in chronic diseases is more than just simple summation of the individual problems.

- $\quad$ The interaction of each problem with others causes suffering to multipy. Also, suffering caused by the same problem may differ among individuals. 
- Therefore such patients require expert trained support that is holistic in scope.

- Patient's families also undergo a great deal of trauma while caring for the patients.Hence, palliative care includes support the patient's families also.

\section{Main symptoms in a terminal cancer patient}

In cancer patients, the symptoms may be caused by primary malignancy, as well as by treatment (surgery, radiotherapy as chemotherapy).

\begin{tabular}{|c|c|}
\hline 1. & General: Pain, cachexia, hiccups, lymhedema etc. \\
\hline 2. & Oral Cavity:Stomatitis /mucositis,dry mouth \\
\hline 3. & GIT:Anorexia,vomiting,dysphagia,peptic ulcers,hematemesis,malaena,intestinal obstruction, \\
& ascites,constipation,diarrhoea \\
\hline 4. & Respiratory symptoms :Dyspnoea,cough,hemoptysis,pleural effusion \\
\hline 5. & Hematological :Anemia,leucopenia,thrombocytopenia,neutropenia \\
\hline 6. & CNS:Headache,papilloedema,altered sensorium,sensory-motor deficit,dilpopia,seizures \\
\hline
\end{tabular}

Table 1: Main symptoms in a Terminal cancer patient $[2,6,7]$.

\begin{tabular}{|c|c|c|}
\hline Symptoms & Causes & Treatment \\
\hline \multicolumn{3}{|l|}{ General } \\
\hline \multirow[t]{3}{*}{ Pain } & $*$ Directly related to tumor & Non-opioids-NSAIDs, paracetamol in the first step \\
\hline & *Indirectly & Weak opioids-Codeine, dextrapropoxyphene in the $2^{\text {nd }}$ step \\
\hline & *Due to therapeutic interventions & $\begin{array}{l}\text { Strong opioids-Morphine, methadone, bupranephrine etc. } \\
\text { in the } 3^{\text {rd }} \text { step }\end{array}$ \\
\hline Hiccups & $\begin{array}{c}\text { Gastric distention, diaphragmatic irritation, phrenic } \\
\text { nerve irritation, brain tumor }\end{array}$ & $\begin{array}{c}\text { Antiflatulents } \\
\text { Metoclopramide } \\
\text { Domperidone } \\
\text { Nasogastic intubation }\end{array}$ \\
\hline Lymphodema & $\begin{array}{l}\text { Surgery/radiotherapy, postoperative } \\
\text { Infection, recurrent disease }\end{array}$ & $\begin{array}{l}\text { Cannot be cure } \\
\text { Diuretics and steroids } \\
\text { Care with moisture }\end{array}$ \\
\hline \multicolumn{3}{|c|}{ Gastrointestinal symptoms } \\
\hline Vomiting & $\begin{array}{l}\text { Gastrointestinal obstruction, infiltration of the wall } \\
\text { of GI tract, liver metastasis, brain or meningeal } \\
\text { metastasis, chemotherapy, electrolyte problems }\end{array}$ & $\begin{array}{l}\text { Antiemetics-Metoclopramide or domperidome } \\
\text { Non-drug measure-small frequent feeds } \\
\text { H2 receptor blocker }\end{array}$ \\
\hline Anorexia & $\begin{array}{l}\text { Vomiting, unappetizing food, dysphagia, uremia, } \\
\text { radiotherapy, chemotherapy }\end{array}$ & $\begin{array}{c}\text { Installment of palatable and easily digestable food } \\
\text { Appetite stimulant } \\
\text { Hyperelimentation }\end{array}$ \\
\hline Diarrhoea & $\begin{array}{l}\text { Laxatives, tube feeding, post gastrectomy dumping } \\
\text { syndrome, carcinoid tumor, radiotherapy, } \\
\text { chemotherapy }\end{array}$ & $\begin{array}{c}\text { Discontinuation of chemotherapy or suspected medication } \\
\text { Oral rehydration } \\
\text { Opioids }\end{array}$ \\
\hline Constipation & $\begin{array}{c}\text { Mass in anorectal region, neurologic and mechanical } \\
\text { changes from surgery, decrease oral intake }\end{array}$ & $\begin{array}{l}\text { Movement and ambulation } \\
\text { Adequate hydration } \\
\text { Use of laxatives }\end{array}$ \\
\hline
\end{tabular}




\begin{tabular}{|c|c|c|}
\hline Ascites & $\begin{array}{c}\text { Peritoneal metastasis, subphrenic lymphatic } \\
\text { obstruction, carcinoma of ovary, pancreas, gall } \\
\text { bladder }\end{array}$ & $\begin{array}{l}\text { Chemotherapy } \\
\text { Diuretics }\end{array}$ \\
\hline \multicolumn{3}{|c|}{ Respiratory symptoms } \\
\hline Dyspnoea & $\begin{array}{l}\text { Pleuropericardial effusion, obstuction of main } \\
\text { bronchus, radiotherapy }\end{array}$ & $\begin{array}{c}\text { Antibiotics } \\
\text { Physiotherapy } \\
\text { Bronchodilator } \\
\text { Breathing exercise }\end{array}$ \\
\hline Cough & $\begin{array}{c}\text { Mechanical irritation of tracheobronchial tree, chest } \\
\text { infection, pleural infection }\end{array}$ & $\begin{array}{l}\text { Antihistamines } \\
\text { Bronchodilators } \\
\text { Diuretics } \\
\text { Antibiotics }\end{array}$ \\
\hline \multicolumn{3}{|c|}{ Oral cavity symptoms } \\
\hline Xerostomia & $\begin{array}{l}\text { Anxiety, depression, hypercalemia, invasion of } \\
\text { salivary gland by cancer }\end{array}$ & $\begin{array}{l}\text { Meticulous mouth care } \\
\text { Chewing gum } \\
\text { Flavoured candies } \\
\text { Artificial saliva }\end{array}$ \\
\hline Oral candidiasis & Dry mouth, corticosteroids and bacterial antibiotics & $\begin{array}{l}\text { Antifungal agent like } \\
\text { Nystatin } \\
\text { Ketoconazole } \\
\text { furconazole }\end{array}$ \\
\hline Metallic taste & $\begin{array}{c}\text { Decreased sensitivity of tastebuds, decreased } \\
\text { number of taste buds, toxic dysfunction of taste } \\
\text { buds, nutrional deficiencies or poor dental hygiene }\end{array}$ & $\begin{array}{l}\text { Reduce area content of diet. } \\
\text { Consumptiom of white meats, diary products,eggs } \\
\text { Consumption of more liquid, fresh fruits and vegetables. }\end{array}$ \\
\hline Halitosis & $\begin{array}{l}\text { Infection, gastric outlet obstruction, smoking or } \\
\text { ingestion of substances like garlic, onion, alcohol }\end{array}$ & $\begin{array}{c}\text { Orodental hygiene } \\
\text { Adequate fluid intake } \\
\text { Treatment of oral candidiasis } \\
\text { Uses of mouthwash }\end{array}$ \\
\hline \multicolumn{3}{|c|}{ Psychiatric symptoms } \\
\hline & Anxiety, depression guilt and self-blame & $\begin{array}{l}\text { Supportive therapy, hyporosis } \\
\text { Relaxation therapy } \\
\text { Pharmocological drugs } \\
\text { Lorazepams, diazepam } \\
\text { Antidepressants } \\
\text { Evaluation tools to assess } \\
\text { Psychological distress. }\end{array}$ \\
\hline
\end{tabular}

Table 2: Common symptoms encountered in patients with Head and Neck cancer and suggested treatments [1,8-19]. 
Role of Radiotherapy in palliative care

Radiotherapy is an indispensable modality in the palliation of cancer. All palliative care programs should be acquainted with its indications (that include pain relief control of hemorrhage, ulceration etc.) and have a close working relationship with a radiation oncology department.

The doses and schedule applies include 500cGy/fraction, 800 cGy/fraction, 20Gy in 5 fractions, 30 Gy in 10 fractions and 40 Gy in 20 fractions $[2,20]$.

Medical education in palliative care

Medical education in palliative care is very important. Particular attention should be given towards basic medical education of clinical student and the training of junior doctors, communication skills and bereavement care.

The cost of palliative care and the optimum place to deliver it, the symptoms of advanced care, pain relief and symptom control method and quality in life in end stage cancer patients are some aspects that should be an integral part of clinical residency program $[2,21]$.

\section{Medicolegal aspects}

The fear of diversion of certain drugs for non medical uses has led to severe control on its availability. The courts have issued directives to improve the availability of the drugs, yet $97 \%$ of Indian patients have very poor access to the drugs.

The government should enforce laws necessitating more hospice and palliative care centers to provide free medical care to terminal cancer patients $[2,22]$.

\section{Conclusion}

Palliative care should be provided by a interdisciplinary and dedicated team consisting of doctor, nurse and ancillary staff.

These patients have unique physical symptoms and emotional needs relating to both the disease and its treatments. Including palliative care clinicians on the treating interdisciplinary team is a key element to improve care for patients with head and neck cancers, as well as for their family caregivers.

Ensuring that these patients-and their families-receive comprehensive supportive services can increase that likelihood that patients will be able to complete life-sustaining treatments and thus obtain the best possible outcomes and quality of life In India,the standard of palliative care is still disappointing as far as facilities are concerned Newer centers for palliative care of cancer patient need to be made available and the public should be made aware in this regard as a form of treatment option.

\section{Bibliography}

1. Goldstein N., et al. "Palliative care for patients with Head and Neck cancer "I would like a Quick Return to a Normal LifeStyle". Journal of the American Medical Association 299.15 (2008): 1818-1825.

2. Suhag V. "Palliative Therapy in cancer patients. An overview". JK Science 7.2 (2005).

3. Principles of Palliative Care. Manual for Palliatibve Care, Chapter 1, Ministry of Health and Family welfare Government of India (2005).

4. Abrahm JL. "Update in palliative medicine and end-of-life care". Annual Review of Medicine 54 (2003): 53-72.

5. Yuen KJ., et al. "Palliative care at home: general practitioners working with palliative care teams". Medicine Journal 179.6 (2003): S38-S40.

6. Walsh D., et al. "The symptomes of advanced cancer: relationship to age,gender, and performance status in 1,000 patients". Support Care Cancer 8.3 (2000):175-179.

7. Morita T., et al. "Contributing factors to physical symptoms in terminally-ill cancer patients". Journal of Pain and Symptom Management 18.5 (1999): 338-346.

8. Portenoy RK and Lesege P. "Management of canacer pain”. Lancet 353.9165 (1999):1695-1700.

9. Takiguchi Y., et al. "Hiccupus as an adverse rection to cancer chemotherapy". Journal of the National Cancer Institute 94.10 (2002): 772-773.

10. Dev SV., et al. "Prevalence and risk factors for development of lymphedema following breast cancer treatment". Indian Journal of Cancer 41.1(2004): 8-12.

11. ballatori E Roila F. "Implant of nausea and vomiting on Quality of life in cancer patients during chemotherapy". Health Qual life out Comes 1 (2003):46.

12. Weitzman S. "Alternative nutritional cancer therapies". International Journal of Cancer 11 (1998): 69-72. 
13. schultz M., et al. Management of chemotherapy induced diarrhea Z Gastro 42.6 (2004): 527-538.

14. Tsuji y., et al. "Management of cancer treatment-related diarrhea and constipation". Nippon Rinsho 61.6 (2003): 966-972.

15. Smith EM and Jayson GC. "The current and future management of malignant ascites". Clinical Oncology (R Coll Radiol) 15.2 (2003): 59-72.

16. Oh EG. "Symptom experience in korean adults with lung cancer". Journal of Pain and Symptom Management 28.2 (2004): 133-139.

17. Wong S., et al. "Five years managing metastatic non smell cell lung cancer; experience ata teaching hospital". Internal Medicine Journal 34.8 (2004): 458-463.

18. Vissink A., et al. "Prevention and treatment of the consequences of head and neck radiotherapy". Critical Reviews in Oral Biology and Medicine 14.3 (2003): 213-225.

19. Kugaya A., et al. "Prevelence, predictive factors, and screening for psychologic distress in patients with newly diagnosed head and neck cancer". Cancer 88.12 (2000): 2817-2823.

20. Ashby M. "The role of radiotherapy in palliative care". Journal of Pain and Symptom Management 6.6 (1991): 380-388.

21. Barclay S., et al. "How common is medical training in palliative care? A postal survey of general practitioners". British Journal of General Practice 47.425 (1997): 800-804.

22. Ghooi RB Ghooi SR. "Freedom from pain-a mirage or a possibility? Experience in attempts to change laws and practices in india". Journal of Pain and Palliative Care Pharmacotherapy 17.3-4 (2003): 1-12.

\section{Volume 3 Issue 10 October 2019}

(C) All rights are reserved by Shubhangi khandekar., et al. 